\title{
A cognitive-creative profile of emotional talent
}

\author{
Rosario Bermejo ${ }^{1, *}$, María Dolores Prieto ${ }^{2}$, Mari Carmen Fernández ${ }^{3}$, Gloria Soto ${ }^{4}$, \\ Marta Sainz ${ }^{5}$ \\ 1Dpto. Psicología Evolutiva y de la Educación, Universidad de Murcia, Spain \{charo@um.es\} \\ 2Dpto. Psicología Evolutiva y de la Educación, Universidad de Murcia, Spain \{lola@um.es\} \\ ${ }^{3}$ Dpto. Psicología Evolutiva y de la Educación, Universidad de Murcia, Spain \{mcfvidal@um.es\} \\ ${ }^{4}$ Dpto. Psicología Evolutiva y de la Educación, Universidad de Murcia, Spain \{gloriasm@um.es\} \\ ${ }^{5}$ Dpto. Psicología Evolutiva y de la Educación, Universidad de Murcia, Spain \{m.gomez@um.es\} \\ Received on 18 October 2012; revised on 29 October 2012; accepted on 3 December 2012; published on 15 January 2013 \\ DOI: $10.7821 /$ naer.2.1.12-16
}

\begin{abstract}
Much attention has been paid to emotional intelligence and its correlations with other psychological constructs during the last few years. Nevertheless, studies focusing on emotionally intelligent persons are scarce. The present work aims to study the cognitive and creative profile of students who stand out for their high emotional intelligence. A total of 1,024 Secondary Education students $(M=14$ years old, $S D=1.16)$ took part in our research to that end. Emotional Intelligence was measured using the Emotional Quotient inventory Youth Version (EQ-i:YV, Bar-on \& Parker, 2000), the Differential Aptitude Test-5 (DAT-5, Bennett, Seashore, \& Wesman, 2000) was used to measure intellectual competency, whereas the Torrance Test of Creative Thinking (TTCT, Torrance, 1974) served to measure creativity. Participants were divided into two groups: those with a high emotional intelligence $(p c>75)$ and those with a low-average emotional intelligence $(p c<75)$. The results reveal statistically significant differences in numerical reasoning, spatial reasoning and perceptive speed favouring the low-average emotional intelligence group. No statistically significant differences were found for creativity dimensions depending on the emotional intelligence level.
\end{abstract}

KEYWORDS: EMOTIONAL INTELLIGENCE, TALENT, COGNITIVE SKILLS, CREATIVITY

It has been just over a decade since Salovey and Mayer (1990) coined the term Emotional Intelligence (EI). Emotional intelligence has been associated with the well-being, leadership, adaptation and performance of subjects (Downey, Mountstephen, Lloyd, Hansen, \& Stough, 2008; Extremera, Fernández-Berrocal, \& Salovey, 2006; Lam \& Kirby, 2002; Petrides, Frederikson, \& Furnham, 2004; Siu, 2009; Villanueva \& Sánchez, 2007). As understood by Mayer, Salovey, Caruso, and Sitarenios (2001), EI describes the ability to recognize the meaning of emotions and their relationships, and to reason and solve problems based on that. It also involves using emotions to enhance cognitive activities. Other authors

${ }^{*}$ To whom correspondence should be addressed:

Universidad de Murcia

Facultad de Educación, Campus de Espinardo

Departamento Psicología Evolutiva y de la Educación

30100 Murcia

Spain have included both cognitive skills and certain personality traits that can facilitate success in life within the concept of emotional intelligence, as in the model suggested by Bar-On (2006), who includes intrapersonal skills (such as self-awareness and selfexpression), interpersonal skills (referring to social awareness and relationships with others), stress management (the ability to handle emotions and self-regulation), adaptability (the ability to go along with change) and general mood (referring to selfmotivation).

Since the concept of emotional intelligence lies half-way between the cognitive and the emotional, early research focused mostly on trying to ensure the construct validity. If emotional intelligence is a form of intelligence different from the g factor, EI is expected to have a low but significant correlation with traditional intelligence (Matthews, Zeidner, \& Roberts, 2002). In this sense, EI has been evaluated and related to psychometric intelligence. The connections found between the two constructs have partly depended on the evaluation method used (Bar-On, 2004; Ciarrochi, Chan, \& Caputi, 2000; Mayer, Caruso, \& Salovey, 2000; Derksen, Kramer, \& Katzko, 2002; Roberts, Zediner, \& Matthews, 2001; Saklofske \& Austin, 2003; Schulte, Ree, \& Carretta, 2004; Van der Zee, Thijs, \& Schakel, 2002; Van Rooy \& Viswesvaran, 2004).

Despite the importance that was initially given to the study of the association between the two variables, emotional intelligence has rarely been studied in relation to high skills. The studies which have addressed it focused on finding the emotional profile that might define high-skilled students, as in the studies conducted by Zeidner, Shani-Zinovich, Matthews, and Roberts (2005); Chan (2003); Schewean, Saklofske, Widdifield-Konkin, Parker, and Kloosterman (2006), and those conducted at the University of Murcia by the High Skills research group (Ferrando, 2006; Ferrando \& Bailey, 2006; Ferrando et al., 2007; Ferrando, Ferrándiz, Bermejo, \& Prieto, 2006; Prieto et al., 2009; Prieto, Ferrándiz, Ferrando, Sánchez, \& Bermejo, 2008; Prieto \& Ferrando, 2008; Prieto et al., 2008). As a rule, the high-skilled students in these studies perceived themselves as having a good EI which was also generally higher than that of their peers.

However, no research has focused on the socio-emotional talent except for the study by Mayer, Perkins, Carusso, and Salovey (2001), who carried out an ethnographic attempt to test the relationship between the concepts of emotional intelligence 
and emotional giftedness, as proposed by Dabrowski (1964). The sample consisted of 11 gifted children (aged 13 to 17) who were given the Multi-Factorial Emotional Intelligence Scale (MEIS) and the Peabody Picture Vocabulary Test (PPVT) (Dunn \& Dunn, 1981). In addition, interviews were conducted to discover how gifted subjects with a high emotional intelligence face difficult situations. The results showed that more emotionally gifted children showed a higher intelligence, more participation in activities, and even more creativity than students with a low EI. The children who obtained the highest emotional intelligence score (regardless of their verbal IQ) seemed to cope better with the different relationships established between their peers than did those with a lower EI. Additionally, students with a higher EI discussed emotional situations with more richness, including the identification of more subtle and sometimes controversial feelings about the people they dealt with, even when compared with students who had achieved a high verbal IQ. Mayer et al. (2001) found that people who had obtained higher scores on EI tests fit in with the emotional giftedness profile proposed by Dabrowski and Piechowski (1977). This profile defines gifted children as well aware of emotions and feelings, with the ability to establish deep and complex relationships with others, and considerably better at establishing the differences between themselves and others.

This study aims to delve into the question of the cognitive and creative profile of students who perceive themselves as talents in the emotional area. Do students with a high EI have a high IQ or high creativity? What defines these students?

\section{METHODOLOGY}

\subsection{Sample}

The study involved a total of 1,024 secondary school students $(M=14$ years, $S D=1.16)$-with a distribution of 494 boys and 530 girls. Of these, 347 were in the 1st year of Secondary School, called ESO (Spanish initials for Compulsory Secondary Education) in Spain's educational system; 173 in the 2nd year of ESO; 369 in 3rd year and 135 in 4th year. All students were registered in centres located in the Murcia and Alicante area. Some of the participating students were nominated for identification as high-skilled students, while another 515 were randomly selected for this study.

\subsection{Tools}

This study has used three types of measuring instruments: the Emotional Quotient Inventory (EQ-i:YV) (Bar-on \& Parker, 2000) was used to assess emotional intelligence. Psychometric intelligence was measured using the Differential Aptitude Test-5 (DAT-5) (Bennett, Seashore, \& Wesman, 2000) and some subtests of the BADyG (Batería de Aptitudes Diferenciales y Generales [Battery of Differential and General Aptitudes]) (Yuste, Martínez, \& Galve, 1998). Finally, creativity was assessed with the Torrance Tests of Creative Thinking (TTCT) (Torrance, 1974). A description of the tools used can be found below:

Table 1. Sample distribution
Emotional Quotient Inventory: Youth Version (Bar-on \& Parker, 2000). This is a self-report instrument for children and teenagers aged 7-18 which consists of 60 statements. Students have to assess the perception of their own emotional intelligence (with a scale ranging from $1=$ it never happens to me; $2=$ it sometimes happens to me; $3=$ it nearly always happens to me; and 4=it always happens to me). The inventory assesses the dimensions of intrapersonal, interpersonal, stress management, adaptability and general mood. Furthermore, the inventory provides a general emotional capacity score. As reported by BarOn and Parker (2000), the questionnaire has adequate internal reliability of the different scales $(\alpha=.84$ for the intrapersonal scale and $\alpha=.89$ for the total test). Ferrándiz, Ferrando, Bermejo, and Prieto (2006) confirmed the factor structure of five factors using a Spanish sample and obtained a .88 reliability for the total scale.

Psychometric intelligence measurement. The Differential Aptitude Test (DAT-5) was used to define cognitive level in various skills:

- Verbal Reasoning: it measures the ability to understand ideas expressed in words. It seeks to assess the student's ability to abstract or generalize and think constructively.

- Calculus: it permits to examine the understanding of numerical relationships and the ability to handle numerical concepts. The purpose is to measure the non-verbal reasoning capacity. In each case, the student must discover which principle is behind the figure transformation and prove it by identifying the diagram that would have to follow in the sequence according to logic.

- Speed and Precision: the purpose is to measure the answering speed in an easy perceptual task.

- Mechanical reasoning: each item consists of a mechanical situation illustrated with a drawing and accompanied by a simple question. The items are knowingly presented according to simple mechanisms, often found in daily life, that do not require any specific knowledge.

- Spatial relations: measures the ability to handle specific materials through visualization.

- Spelling and Language: in this case, the tests are more a matter of performance rather than aptitude. Different scores are obtained for both tests, although there are few cases in which just one of these abilities is needed. Jointly considered, they provide a correct estimate of the student's ability to distinguish between correct usage and incorrect language (a skill required in shorthand, journalism, advertising, etc.)

A verbal memory from the BADyG was additionally used (Yuste et al., 1998). A factorial analysis of the cognitive skills measured allowed us to check that they were grouped in a single factor -called "single intelligence factor" in our paper.

Measuring creativity. The parallel lines test of the TTCT protocol designed by Torrance (1974) served to measure creativity. This test asks students to do as many different drawings as they can only using parallel lines. It then measures

\begin{tabular}{ccccccccc}
\hline & \multicolumn{3}{c}{ GENDER } & \multicolumn{5}{c}{ ACADEMIC YEAR } \\
\cline { 2 - 9 } & M. & F. & Total & 1st ESO & 2nd ESO & 3rd ESO & 4th ESO & Total \\
\cline { 2 - 9 } Low and average EI $(p c<75)$ & 363 & 384 & 747 & 250 & 109 & 290 & 98 & 747 \\
High EI $(p c>75)$ & 131 & 146 & 277 & 97 & 64 & 79 & 37 & 277 \\
Total & 494 & 530 & 1.024 & 347 & 173 & 369 & 135 & 1.024 \\
\hline \hline
\end{tabular}


the dimensions of fluidity (number of drawings completed), flexibility (the number of different categories used), originality (whether the answers are unusual) and elaboration (details are not necessary to convey the main idea). The test was adapted to the Spanish context and proved to be reliable (Oliveira et al., 2009). In our study, the figurative expression test served to assess the imagination level in drawings, specifically the 3rd sub-test, the Parallel Lines test, since in previous studies this test explained a greater percentage of variance (Almeida, Prieto, Ferrando, Oliveira, \& Ferrándiz, 2008; Ferrando et al., 2007; Oliveira et al., 2009; Prieto et al., 2006).

\section{PROCEDURE}

Parents and teachers were firstly informed about the purposes of this study. Then, the participating students completed the intelligence, emotional intelligence and creativity test following the authors' instructions during a number of sessions agreed with the teachers.

The sample was divided in two groups with the aim of studying the cognitive and creative profile of students who perceive themselves as having a high emotional intelligence. One group included those students who perceived themselves as having a percentile above 75 in the EI total score. The second group was formed by students with a score below the 75 percentile in EI.

The total emotional quotient score was calculated (by adding up all the items, except those in the scale of positive impressions) together with the 75 percentile cut-off point. Since statistically significant differences were found among students depending of the course that they attended, a decision was made to calculate the 75 percentile for each course so as to avoid the possible influence of the age.

Following this criterion, 277 students showed a percentile equal or higher than 75 in their EI score, whereas the rest of their peers (747) showed an average-low emotional intelligence.

The data analysis carried out was based on descriptive analyses (with averages and standard deviations) and average comparisons through the Student's $t$-test.

\section{RESULTS}

The descriptive statistics for the scores obtained by participants in the different dimensions of psychometric intelligence and creativity (Tables 2 and 3) were estimated first, after which an analysis of the mean differences was performed for the purpose of comparing high-EI students and the rest of their colleagues.

As can be seen in Table 2 and in Figure 1, students who perceive themselves as having a greater emotional talent are the ones who obtain a lower score in almost all the psychometric intelligence variables. Specifically, students with a high EI obtain lower scores than their mates in the areas of numerical reasoning, abstract reasoning, spatial reasoning, spelling, and in the areas of perceptive speed and accuracy.

Such differences turned out to be statistically significant for the areas of Numerical Reasoning [ $t(529.984)=2.715 ; p=.007]$, Spatial Reasoning [t(1.018) $=-1.914 ; p=.056]$, verbal and Numerical Reasoning [t(1017) $=-2.045 ; p=.041]$ and Perceptive Speed [t(455.578) $=-2.439 ; \mathrm{p}=.015]$.
Table 2. Descriptive statistics for the psychometric intelligence dimensions

\begin{tabular}{|c|c|c|c|c|c|c|}
\hline \multirow[b]{3}{*}{ Verbal R. } & \multicolumn{2}{|c|}{$\begin{array}{c}\text { Total sample } \\
(N=1.024)\end{array}$} & \multicolumn{2}{|c|}{$\begin{array}{c}\text { Low and average } \\
\text { EI }(N=747)\end{array}$} & \multicolumn{2}{|c|}{$\begin{array}{r}\text { High EI } \\
(N=277)\end{array}$} \\
\hline & $\begin{array}{l}\text { Min- } \\
\text { Max. }\end{array}$ & $M(S D)$ & $\begin{array}{l}\text { Min- } \\
\text { Max. }\end{array}$ & $M(S D)$ & $\begin{array}{l}\text { Min- } \\
\text { Max. }\end{array}$ & $\mathrm{M}(S D)$ \\
\hline & $5-63$ & $\begin{array}{l}23.08 \\
(6.72)\end{array}$ & $7-63$ & $\begin{array}{l}23.21 \\
(6.80)\end{array}$ & $5-37$ & $\begin{array}{l}22.71 \\
(6.46)\end{array}$ \\
\hline Numerical R. & $4-38$ & $\begin{array}{l}19.89 \\
(6.82) \\
\end{array}$ & $4-38$ & $\begin{array}{l}20.21 \\
(7.03) \\
\end{array}$ & $6-35$ & $\begin{array}{l}18.98 \\
(6.10) \\
\end{array}$ \\
\hline Abstract R. & $2-63$ & $\begin{array}{l}26.48 \\
(9.16) \\
\end{array}$ & $2-63$ & $\begin{array}{l}26.74 \\
(9.27) \\
\end{array}$ & $4-40$ & $\begin{array}{l}25.74 \\
(8.80)\end{array}$ \\
\hline $\begin{array}{c}\text { Mechanical } \\
\text { R. }\end{array}$ & $9-57$ & $\begin{array}{l}35.05 \\
(8.56)\end{array}$ & $9-56$ & $\begin{array}{l}35.02 \\
(8.75)\end{array}$ & $11-57$ & $\begin{array}{l}35.11 \\
(8.00)\end{array}$ \\
\hline Spatial R. & $1-50$ & $\begin{array}{c}28.13 \\
(11.27)\end{array}$ & $1-50$ & $\begin{array}{c}28.53 \\
(11.34)\end{array}$ & $4-49$ & $\begin{array}{c}26.99 \\
(10.99)\end{array}$ \\
\hline Spelling & $1-46$ & $\begin{array}{l}29.14 \\
(7.24)\end{array}$ & $3-40$ & $\begin{array}{l}29.33 \\
(7.28)\end{array}$ & $1-46$ & $\begin{array}{l}28.62 \\
(7.11)\end{array}$ \\
\hline $\begin{array}{l}\text { Verbal and } \\
\text { numerical R. }\end{array}$ & $4-90$ & $\begin{array}{c}42.85 \\
(12.28)\end{array}$ & $10-90$ & $\begin{array}{c}43.32 \\
(12.48)\end{array}$ & $4-70$ & $\begin{array}{c}41.53 \\
(11.65)\end{array}$ \\
\hline $\begin{array}{c}\text { Perceptive } \\
\text { speed }\end{array}$ & $1-99$ & $\begin{array}{c}55.02 \\
(12.72) \\
\end{array}$ & $1-99$ & $\begin{array}{c}55.6 \\
(12.67) \\
\end{array}$ & $5-85$ & $\begin{array}{c}53.37 \\
(12.73) \\
\end{array}$ \\
\hline Memory & $3-86$ & $\begin{array}{l}22.18 \\
(6.89) \\
\end{array}$ & $3-86$ & $\begin{array}{l}22.13 \\
(6.93) \\
\end{array}$ & $3-78$ & $\begin{array}{l}22.32 \\
(6.78) \\
\end{array}$ \\
\hline
\end{tabular}

Figure 1. Average scores for students with a high EI ( $p c>75)$ and a lowaverage EI $(p c<75)$ for the psychometric intelligence dimensions

$$
\multimap \text { Low-Average EI }(\mathrm{pc}<75 \mathrm{n}=747) \quad \multimap \quad \text { High EI }(\mathrm{pc}>75, \mathrm{n}=277)
$$

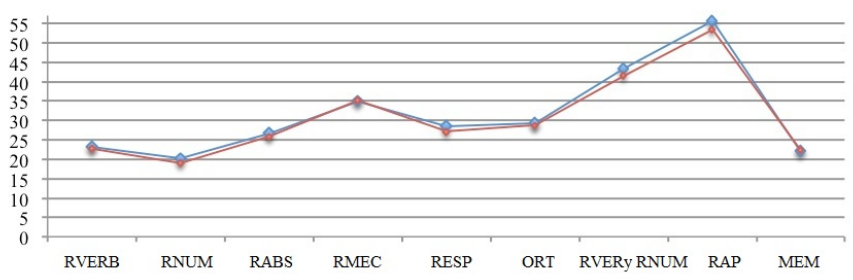

RVERB: Verbal reasoning, RNUM: Numerical reasoning, RABS: Abstract reasoning, RMEC: Mechanical reasoning, RESP: Spatial reasoning, ORT: Spelling, RVERyRNUM: Verbal and numerical reasoning, RAP: Perceptive speed, MEM: Memory.

Regarding Creativity (Table 3 and Figure 2), students with a high EI obtained a higher score in Originality $[t(519)=$ $1.354 ; p=.176]$ and Elaboration $[t(519)=0.989 ; p=.323]$; however, these differences are not statistically significant.

Table 3. Descriptive statistics for the creative thinking dimensions

\begin{tabular}{ccccccc}
\hline & \multicolumn{2}{c}{$\begin{array}{c}\text { Total sample } \\
(N=1.024)\end{array}$} & \multicolumn{2}{c}{$\begin{array}{c}\text { Low and average } \\
\text { EI }(N=747)\end{array}$} & \multicolumn{2}{c}{$\begin{array}{c}\text { High EI } \\
(N=277)\end{array}$} \\
\cline { 2 - 7 } & $\begin{array}{c}\text { Min- } \\
\text { Max. }\end{array}$ & $M(S D)$ & $\begin{array}{c}\text { Min- } \\
\text { Max. }\end{array}$ & $M(S D)$ & $\begin{array}{c}\text { Min- } \\
\text { Max. }\end{array}$ & $M(S D)$ \\
\cline { 2 - 7 } Originality & $0-64$ & $\begin{array}{c}25.38 \\
(13.81)\end{array}$ & $0-62$ & $\begin{array}{c}24.77 \\
(13.85)\end{array}$ & $0-64$ & $\begin{array}{c}26.47 \\
(13.69)\end{array}$ \\
\hline Elaboration & $0-60.5$ & $\begin{array}{c}15.08 \\
(8.53)\end{array}$ & $0-60.5$ & $\begin{array}{c}14.81 \\
(8.62)\end{array}$ & $\begin{array}{c}0- \\
50.5\end{array}$ & $\begin{array}{c}15.57 \\
(8.37)\end{array}$ \\
\hline Fluency & $0-30$ & $\begin{array}{c}14.21 \\
(6.85)\end{array}$ & $0-30$ & $\begin{array}{c}14.19 \\
(6.94)\end{array}$ & $0-30$ & $\begin{array}{c}14.25 \\
(6.71)\end{array}$ \\
\hline Flexibility & $0-24.5$ & $\begin{array}{c}11.04 \\
(4.86)\end{array}$ & $0-24.5$ & $\begin{array}{c}11.00 \\
(4.94)\end{array}$ & $\begin{array}{c}0- \\
24.5\end{array}$ & $\begin{array}{c}11.132 \\
(4.73)\end{array}$ \\
\hline
\end{tabular}


Figure 2. Average scores for students with a high EI ( $p c>75)$ and a lowaverage EI $(p c<75)$ for the creative thinking dimensions

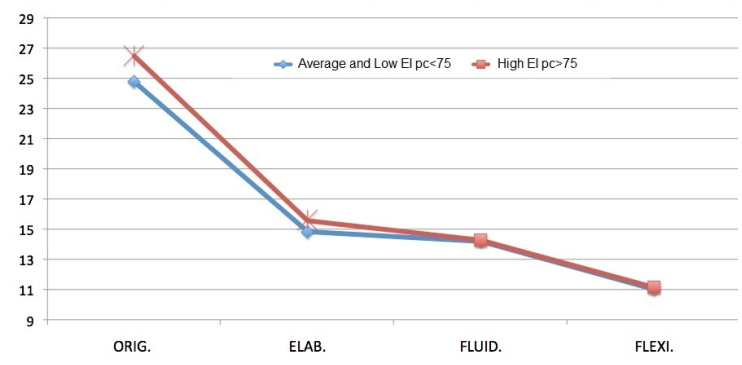

ORIG: Originality, ELAB: Elaboration, FLUID: Fluidity, FEXI: Flexibility

\section{CONCLUSION AND DISCUSSION}

Emotional Intelligence has been associated with success in life, and research has tried to study its connection to intelligence as well. There have even been comparative studies which examined the EI of the most intelligent subjects and that of subjects with an average intelligence. However, previous research rarely deepened into the characteristics which are shared by people with a high emotional intelligence.

This study sought to find the common characteristics regarding the cognitive and creative profile of students with a high self-perceived emotional intelligence, comparing them with their colleagues who had a low or average emotional intelligence.

Previous research studies had found a positive correlation between EI and verbal reasoning (Ciarrochi et al., 2000; Mayer et al., 2000; Derksen et al., 2002; Roberts et al., 2001; Saklofske \& Austin, 2003; Van der Zee et al., 2002; Van Rooy \& Viswesvaran, 2004). Moreover, studies carried out with gifted or talented pupils have shown that these students usually achieve a higher score than their colleagues in emotional intelligence tests (Chan, 2003; Prieto \& Ferrando, 2008; Schewean et al., 2006; Zeidner et al., 2005).

Since it was repeatedly verified in the past that a significant correlation exists between emotional intelligence and verbal reasoning, it was to be expected that the pupils with a high-EI analysed in our study would also obtain higher scores in verbal reasoning; however, this was not the case.

Furthermore, although the most intelligent students analysed in previous studies were the ones who also showed a higher emotional intelligence, students with a high EI in our study did not stand out in any cognitive area. The results even reveal that students with a high emotional intelligence show fewer capacities than their colleagues in the areas of numerical reasoning, spatial reasoning and perceptive speed. Students with a high EI even seem to be the "clumsy" ones in the group, in which case -could this possibly be explained with the theory of compensation? If these students see that their intellectual resources are limited, they may have to make an effort in other non-cognitive to compensate for their weaknesses.

Regarding creativity, no differences were found between students with a high EI and the rest of their colleagues. Our results are in keeping with previous studies, which had found a low or non-significant correlation between both variables (Ferrando, 2006).

\section{REFERENCES}

Almeida, L., Prieto, M. D., Ferrando, M., Oliveira, E., \& Ferrándiz, C. (2008). Torrance Test of Creative Thinking: the question of its construct validity. Thinking Skills and Creativity, 3, 53-58. doi:10.1016/j.tsc.2008.03.003

Bar-On, R. (2004). The Bar-On Emotional Quotient Inventory (EQ-i): Rationale, description, and summary of psychometric properties. In Glenn Geher (Ed.), Measuring emotional intelligence: Common ground and controversy (pp. 111-142). Hauppauge, NY: Nova Science Publishers.

Bar-On, R. (2006). The Bar-On Model of emotional-social intelligence (ESI) Psicothema, 18, supl., 13-25.

Bar-On, R., \& Parker J. D. (2000). EQ-i:YV. Bar-On Emotional Quotient Inventory: Youth Version. Technical Manual. New York: MHS.

Bennett, G., Seashore, G., \& Wesman, A. (2000). DAT-5, Test de Aptitudes Diferenciales. Madrid: TEA Ediciones.

Chan, D. W. (2003). Dimensions of Emotional Intelligence and Their Relationships with Social Coping Among Gifted Adolescents in Hong Kong. Journal of Youth and Adolescence, 32(6), 409-418. doi:10.1023/A:1025982217398

Ciarrochi, J. V., Chan, A. Y .C., \& Caputi, P. (2000). A critical evaluation of the emotional intelligence construct. Personality and individual differences, 28, 539-56. doi:10.1016/S0191-8869(99)00119-1

Dabrowski, K. (1964). Positive Disintegration. London: Little Brown.

Dabrowski, K., \& Piechowski, M. M. (1977). Theory of levels of emotional develompment (vol.1, Multilevelness and positive disintegration). Oceanside, NY. Dabor.

Derksen, J., Kramer, I., \& Katzko, M. (2002). Does a self-report measure for emotional intelligence assess something different than general intelligence? Personality and Individual Differences. 31(1), 37-48. doi:10.1016/S0191-8869(01)00004-6

Downey, L. A., Mountstephen, J., Lloyd, J., Hansen, K., \& Stough, C. (2008). Emotional intelligence and scholastic achievement in Australian adolescents. Australian Journal of Psychology, 60, 10-17. doi:10.1080/00049530701449505

Dunn, L. M., \& Dunn, L. M. (1981). PPVT-R: Peabody Picture Vocabulary Test Revised. Circles Pines MN, American Guidance Service (AGS) Publishing.

Extremera, N., Fernández-Berrocal, P., \& Salovey, P. (2006). Spanish version of the Mayer-Salovey-Caruso Emotional Intelligence Tests (MSCEIT Versión 2.0): Reliabilities, age and gender differences. Psicothema, 18, 42-48.

Ferrándiz, C., Ferrando, M., Bermejo, R., \& Prieto, L. (2006). Emotional intelligence and personality. Lecture presented to The Annual Meeting of the British Educational Research Association (BERA), celebrated in Warwick (UK), from 6th to 9th September.

Ferrando, M. (2006). Creatividad e Inteligencia Emocional: Un estudio empírico en alumnos con altas habilidades. Doctoral thesis. Universidad de Murcia.

Ferrando, M., \& Bailey, R. (2006). Emotional Intelligence in G\&T: a Pilot Study. Paper presented to the British Educational Research Association (BERA). September Warwick University (UK).

Ferrando, M., Ferrándiz, C., Bermejo, M. R., Sánchez, C., Parra, J., \& Prieto, M.D. (2007). Estructura Interna y Baremación del Test de Pensamiento Creativo de Torrance. Psicothema, 3(19), 489-496.

Ferrando, M., Ferrandiz, C., Prieto, M. D., Sánchez, C., Hernandez, D, Serna, B., \& Lopez, J. (2007). Socio-Emotional Intelligence in G\&T and Non-G\&T Pupils. Paper presented to the World Council for Gifted and Talented Children, 17th Biennial World Conference. University of Warwick (UK).

Ferrando, M., Ferrándiz, C., Bermejo, R., \& Prieto, M.D. (2006). Inteligencia Emocional y superdotación. (Emotional Intelligence and Giftedness) In A. A. Candeias (Coord.) (2006), Crianças Diferentes: Múltiplos olhares sobre como avaliar e intervir (different children: multiple looks about how to validate and intervene) (pp: 76-102). Évora: Universidade de Évora.

Lam, L. T. \& Kirby, S. L. (2002). Is emotional intelligence an advantage? An exploration of the impact of emotional and general intelligence on individual performance. Journal of Social Psychology, 142, 133-145. doi:10.1080/00224540209603891

Matthews, G., Zeidner, M., \& Robersts R.M. (2002). Emotional Intelligence. Science and Myth. London: MIT Press.

Mayer, J. D., Caruso, D. R., \& Salovey, P. (2000). Emotional intelligence meets traditional standards for an intelligence. Intelligence, 27, 267-298. doi:10.1016/S0160-2896(99)00016-1 
Mayer, J. D., Perkins, D. M., Caruso, D., \& Salovey, P. (2001). Emotional intelligence and giftedness. Roeper Review, 23, 131-137. doi: 10.1080/02783190109554084

Mayer, J. D., Salovey, P., Caruso, D. R., \& Sitarenios, G. (2001). Emotional intelligence as a standard intelligence. Emotion, 1, 232-242. doi: 10.1037/1528-3542.1.3.232

Oliveira, E. P., Almeida, L., Ferrándiz, C., Ferrando, M., Sáinz, M., \& Prieto, M. D. (2009). Tests de Pensamiento Creativo de Torrance (TTCT): Elementos para la validez del constructo en adolescentes portugueses. Psicothema, 21(4), 562-567.

Petrides, K. V., Frederikson, N., \& Furnham, A. (2004). The role of trait emotional intelligence in academic performance and deviant behaviour at school. Personality and Individual Differences, 36, 277-293. doi: 10.1016/S0191-8869(03)00084-9

Prieto, M. D., \& Ferrando, M. (2008). Prejudices about Emotional Intelligence in Gifted and Talented Children. In T. Balchin, B. Hymer, \& D. Matthews. (Eds.). The Routledge International Companion to Gifted Education (pp. 149-154). New York: RoutledgeFarmer.

Prieto, M. D., Fernández, M. C., Ferrando, M., Hernández, D., Llor, L., \& Almeida, L. (2009). Gifted and non-gifted students: Do they differ in their socio-emotional competences? In P. Fernández-Berrocal et al. (Coords.), Avances en el estudio de la Inteligencia Emocional. [In advances in the study of Emotional Intelligence] (pp. 467-472). Santander: Fundación Marcelino Botín.

Prieto, M. D., Ferrándiz, C., Ferrando, M., Sánchez, C., \& Bermejo, M. R. (2008). Inteligencia emocional y alta habilidad. Revista Española de Pedagogía, 240, 240-260.

Prieto, M. D., Ferrándiz, C., Ferrando, M., Sáinz, M., Bermejo, M. R., \& Hernández, D. (2008). Inteligencia emocional en alumnos superdotados: Un estudio comparativo entre España e Inglaterra. Revista de Investigación Psicoeducativa, 6(2), 297-320.

Prieto, M. D., Parra, J., Ferrando, M., Ferrándiz, C., Bermejo, M. R., \& Sánchez, C. (2006). Creative abilities in early childhood. Journal of Early Childhood Research, 4(3), 277-290. doi: 10.1177/1476718X06067580

Roberts, R. D., Zeidner, M., \& Matthews, G. (2001) Does Emotional Intelligence Meet Traditional Standards for an Intelligence? Some New Data and Conclusions. Emotion, 1(3), 196-231. doi:10.1037/1528-3542.1.3.196

Saklofske, D. H., \& Austin, E. J. (2003). Factor structure and validity of a trait emotional intelligence measure. Personality and Individual Differences, 34(4), 707-721. doi:10.1016/S0191-8869(02)00056-9

Salovey, P., \& Mayer, J. (1990). Emotional intelligence. Imagination, cognition, and personality, 9(3), 185-211. doi:10.2190/DUGG-P24E52WK-6CDG

Schewean, V. L., Saklofske, D. H., Widdifield-Konkin, L., Parker, J., \& Kloosterman, P. (2006). Emotional Intelligence and Gifted Children. E-Journal of Applied Psychology: Emotional Intelligence, 2(2), 3037.

Schulte, M. J., Ree, M. J., \& Carretta, T. R. (2004) Emotional intelligence: not much more than $g$ and personality. Personality and individual differences, 37(5), 1059-1068. doi:10.1016/j.paid.2003.11.014

Siu, A. F. Y. (2009). Trait emotional intelligence and its relationships with problem behavior in Hong Kong adolescents. Personality and Individual Differences, 47, 553-557. doi:10.1016/j.paid.2009.05.004

Torrance, E. P. (1974). The Torrance Tests of Creative Thinking Norms-Technical Manual Research Edition - Verbal Tests, Forms A and B - Figural Tests, Forms A and B. Princeton NJ: Personnel Press.

Van der Zee, K., Thijs, M., \& Schakel, L. (2002). The relationship of emotional intelligence with academic intelligence and the Big Five. European Journal of Personality, 16(2002), 103-125. doi:10.1002/per.434

Van Rooy, D. L., \& Viswesvaran, C. (2004). Emotional intelligence: A meta-analytic investigation of predictive validity and nomological net. Journal of Vocational Behavior, 65, 71-95. doi:10.1016/S00018791(03)00076-9

Villanueva, J. J., \& Sánchez, J. C. (2007). Trait Emotional Intelligence and Leadership Self-Efficacy: Their Relationship with Collective Efficacy. The Spanish Journal of Psychology, 10, 349-356.

Yuste, C., Martínez, R., \& Galve, J. L. (1998). Manual Técnico de la Batería de Aptitudes Diferenciales y Generales (BADyG) Superior Renovada. Madrid: CEPE.

Zeidner, M., Shani-Zinovich, I., Matthews, G., \& Roberts, R. D. (2005) Assessing Emotional Intelligence in gifted and non-gifted school stu- dents: Outcomes depending on the measure. Intelligence, 33, 369391. doi:10.1016/j.intell.2005.03.001

\section{ACKNOWLEDGMENT}

This article has been funded by the Fundación Séneca and the Spanish Ministry of Education and Science (11896/PHCS/09. EDU2010-16370) 